\title{
Recent advances in the understanding of renal inflammation
}

\section{and fibrosis in lupus nephritis [version 1; peer review: 2}

\section{approved]}

\author{
Susan Yung, Desmond YH Yap, Tak Mao Chan (ib \\ Department of Medicine, University of Hong Kong, Hong Kong, Hong Kong
}

V1 First published: 13 Jun 2017, 6(F1000 Faculty Rev):874

https://doi.org/10.12688/f1000research.10445.1

Latest published: 13 Jun 2017, 6(F1000 Faculty Rev):874

https://doi.org/10.12688/f1000research.10445.1

\begin{abstract}
Lupus nephritis is a potentially reversible cause of severe acute kidney injury and is an important cause of end-stage renal failure in Asians and patients of African or Hispanic descent. It is characterized by aberrant exaggerated innate and adaptive immune responses, autoantibody production and their deposition in the kidney parenchyma, triggering complement activation, activation and proliferation of resident renal cells, and expression of proinflammatory and chemotactic molecules leading to the influx of inflammatory cells, all of which culminate in destruction of normal nephrons and their replacement by fibrous tissue. Anti-doublestranded DNA (anti-dsDNA) antibody level correlates with disease activity in most patients. There is evidence that apart from mediating pathogenic processes through the formation of immune complexes, pathogenic anti-dsDNA antibodies can bind to resident renal cells and induce downstream pro-apoptotic, pro-inflammatory, or pro-fibrotic processes or a combination of these. Recent data also highlight the critical role of macrophages in acute and chronic kidney injury. Though clinically effective, current treatments for lupus nephritis encompass non-specific immunosuppression and the antiinflammatory action of high-dose corticosteroids. The clinical and histological impact of novel biologics targeting pro-inflammatory molecules remains to be investigated. Insight into the underlying mechanisms that induce inflammatory and fibrotic processes in the kidney of lupus nephritis could present opportunities for more specific novel treatment options to improve clinical outcomes while minimizing off-target untoward effects. This review discusses recent advances in the understanding of pathogenic mechanisms leading to inflammation and fibrosis of the kidney in lupus nephritis in the context of established standard-of-care and emerging therapies.
\end{abstract}

Keywords

Lupus nephritis, AKI, acute kidney injury, renal failure, SLE

\section{Open Peer Review \\ Approval Status \\ 1 \\ 2 \\ version 1 \\ 13 Jun 2017 \\ Faculty Reviews are review articles written by the prestigious Members of Faculty Opinions. The articles are commissioned and peer reviewed before publication to ensure that the final, published version is comprehensive and accessible. The reviewers who approved the final version are listed with their names and affiliations. \\ 1. Anne Davidson, Center for Autoimmunity and Musculoskeletal Diseases, Manhasset, USA}

2. Chaim Putterman, Albert Einstein College of Medicine, Bronx, USA

Any comments on the article can be found at the end of the article. 
Corresponding author: Tak Mao Chan (dtmchan@hku.hk)

Competing interests: The authors declare that they have no competing interests.

Grant information: Studies undertaken by TMC's group [1, 4, 10, 12, 14-17, 22, 31, 39] were funded by the RGC General Research Fund (HKU 7366/04M, 7550/06M, 7604/10M, HKU 7607/12M, 17100914, and 17126814) and UGC Matching Grant Schemes (Phases IV, V, and VI). SY is supported by the Wai Hung Charitable Foundation Limited and the 'Yu Chiu Kwong Professorship in Medicine' Endowment Fund awarded to TMC.

The funders had no role in study design, data collection and analysis, decision to publish, or preparation of the manuscript.

Copyright: @ 2017 Yung S et al. This is an open access article distributed under the terms of the Creative Commons Attribution License, which permits unrestricted use, distribution, and reproduction in any medium, provided the original work is properly cited.

How to cite this article: Yung S, Yap DY and Chan TM. Recent advances in the understanding of renal inflammation and fibrosis in lupus nephritis [version 1; peer review: 2 approved] F1000Research 2017, 6(F1000 Faculty Rev):874

https://doi.org/10.12688/f1000research.10445.1

First published: 13 Jun 2017, 6(F1000 Faculty Rev):874 https://doi.org/10.12688/f1000research.10445.1 


\section{Introduction}

Lupus nephritis (LN) is a severe manifestation of systemic lupus erythematosus (SLE) and is associated with a sixfold increase in mortality compared with the general population ${ }^{1}$. Up to $60 \%$ of patients with SLE will develop LN at some stage during the course of disease, the percentage depending on race, ethnicity, and healthcare availability ${ }^{1-3}$. $\mathrm{LN}$ is characterized by loss of self-tolerance, production of autoantibodies to nuclear autoantigens, immune complex deposition, and immune-mediated injury to the kidney parenchyma. Clinically, $\mathrm{LN}$ is characterized by periods of remission interspersed with episodes of disease activity or flares. If these inflammatory processes are not effectively and rapidly controlled, glomerulosclerosis, interstitial fibrosis, tubular atrophy, and progressive kidney failure will follow, leading to end-stage renal failure requiring renal replacement therapy. Treatment of LN has evolved considerably over the past few decades from reliance on corticosteroids alone to different combination immunosuppressive regimens, and the optimal choice is informed by the type and severity of nephritis, the phase in the natural history of disease, and patient characteristics ${ }^{4}$. It has been reported that approximately $30 \%$ of patients eventually will progress to end-stage renal failure $^{3,5}$. Identifying key elements in the pathogenesis of inflammation and fibrosis or important checkpoints leading to kidney damage could present opportunities for novel means of therapeutic intervention to further improve clinical outcomes.

\section{Overview of lupus nephritis pathogenesis}

LN is initiated by the deposition of anti-double-stranded DNA (anti-dsDNA) antibody-containing immune complexes in the kidney parenchyma resulting in complement activation, infiltration of immune cells, increased activation and proliferation of resident renal cells, and immune-mediated kidney injury. The precise location of immune complexes in the glomerulus and tubulointerstitium, their size, ability to activate complement, and the effectiveness of complex-clearing mechanisms dictate the severity of proliferative and inflammatory responses in the kidney. The glomerulus is the predominant site for immune complex deposition. Deposition within the mesangium is accompanied by mesangial hypercellularity and increased matrix synthesis, whereas their deposition in the subendothelium induces endothelial cell injury, endocapillary proliferation and infiltration of circulating myeloid cells into the kidney ${ }^{6}$. Injury to endothelial cells induces the release of apoptotic microparticles that drive dendritic cell activation and prime neutrophils for NETosis, which further exacerbates inflammatory processes ${ }^{7}$. Subepithelial deposits promote podocyte injury with restricted immune cell infiltration unless the glomerular basement membrane (GBM) ruptures ${ }^{8}$. The most severe forms of LN (classes III and IV) are characterized by inflammatory and proliferative glomerular lesions resulting in fibrosis and loss of renal function'. Immune deposits have also been detected in the tubular basement membrane in up to $70 \%$ of patients with LN, especially those with class III or IV LN, and the quantity of immune complex deposition correlates with the severity of tubulo-interstitial inflammation ${ }^{10,11}$.
Anti-dsDNA antibody production is a cardinal feature of $\mathrm{LN}$, and serum levels often correlate with disease activity ${ }^{12,13}$. There is evidence that in addition to contributing to immune complex formation, pathogenic anti-dsDNA antibodies can bind to resident renal cells and induce downstream apoptotic, inflammatory, and fibrotic processes ${ }^{10,12,14-20}$. There is increasing evidence to suggest that the pathogenic potential of anti-dsDNA antibodies is not dependent on its interaction with dsDNA per se since dsDNA is poorly immunogenic ${ }^{21}$ but is instead reliant on its poly-reactive nature and ability to bind to cross-reactive antigens on the surface of resident renal cells or constituents of their extracellular matrix $^{22-24}$. Many of the studies relating to anti-dsDNA antibodies binding to resident renal cells have focused on mesangial cells and currently there are limited data on the interaction of anti-dsDNA antibodies with glomerular endothelial cells, podocytes, and proximal tubular epithelial cells (PTECs). Anti-dsDNA antibodies have also been reported to bind to nucleosomes that are released into the circulation from either circulating or intra-glomerular apoptotic cells, which are then entrapped within the GBM. Recently, Olin et al. demonstrated that laminin $\beta 1$, an extracellular matrix component induced in resident renal cells by transforming growth factor-beta 1 (TGF- $\beta 1$ ) during tissue fibrosis, entrapped nucleosomes in electron-dense deposits in the GBM which could serve as antigens for anti-dsDNA antibodies ${ }^{25}$. Although there has been much debate on the mechanisms that mediate anti-dsDNA antibody binding to the kidney parenchyma, distinct mechanisms may operate in different renal compartments and possibly at different phases of disease.

The pathogenic mechanisms of anti-dsDNA antibodies remain controversial. Non-dsDNA-binding antibodies may also contribute to kidney injury. Dissociation between anti-dsDNA antibody deposition and LN has also been reported in experimental models of LN. In NZM2328.Lc4 mice, intra-glomerular immune complex deposition and fatal $\mathrm{LN}$ occurred in the absence of anti-dsDNA antibodies ${ }^{26}$. Furthermore, lupus-prone mice deficient in Stat4, a transcription factor that drives Th1 responses, displayed accelerated nephritis compared with their wild-type littermates in the absence of anti-dsDNA antibodies ${ }^{27}$. The mode of kidney inflammation could be more important than anti-dsDNA antibodies per se in the initiation and progression of $\mathrm{LN}^{27}$. Biopsy-proven LN can occur in patients without anti-dsDNA antibodies in the circulation $^{28}$. Discordance between circulating anti-dsDNA antibody titres and activity of LN may also be attributed to the different dsDNA substrates used in immunoassays ${ }^{29}$.

\section{Recent knowledge on renal inflammation in lupus nephritis}

(a) Role of resident kidney cells

The mesangium is the site for anti-dsDNA antibody-containing immune complex deposition in the glomerulus in less severe forms of LN, and mesangial immune deposits are always present in severe nephritis. $\mathrm{We}^{22}$ and others ${ }^{23,30}$ have reported that antidsDNA antibodies can bind directly to mesangial cells through 
cell surface annexin II or $\alpha$-actinin. The functional consequence of anti-dsDNA antibody binding to $\alpha$-actinin on mesangial cells has not been defined. Binding of anti-dsDNA antibodies to mesangial annexin II resulted in the activation of mitogen-activated protein kinase (MAPK) and AKT/phosphoinositide 3-kinase (AKT/PI3K) signaling pathways and increased IL-6 secretion and annexin II expression. That anti-dsDNA antibodies can augment increased annexin II expression in mesangial cells suggests potential amplification of immune-mediated inflammation in the glomerulus ${ }^{22}$. At the ultrastructural level, annexin II localized to the surface of mesangial cells and in the mesangial matrix and also with electron-dense immune deposits along the $\mathrm{GBM}^{31}$. Annexin II can co-localize with immunoglobulin $\mathrm{G}$ ( $\mathrm{IgG}$ ) and complement 3 (C3) deposition in human and murine LN, thus underscoring the pathogenic role of annexin II and its interaction with anti-dsDNA antibodies in $\mathrm{LN}^{22}$. Anti-dsDNA antibodies can induce gene or protein expression (or both) of pro-inflammatory mediators such as interleukin-1 beta (IL-1 $\beta$ ), tumor necrosis factoralpha (TNF- $\alpha$ ), hyaluronan, lipocalin-2, monocyte chemoattractant protein-1 (MCP-1), (C-X-C motif) ligand 1 (CXCL1)/ $\mathrm{KC}, \mathrm{CX} 3 \mathrm{CL}$, and inducible nitric oxide synthase in cultured human or murine mesangial cells ${ }^{15,17,22,32}$. The induction of these pro-inflammatory mediators is facilitated through the binding of high-mobility group box 1 protein, engagement of Toll-like receptor 2 (TLR-2) and receptor for advanced glycation end-products (RAGE), activation of the MAPK, protein kinase C (PKC), inhibitor of kappa-light chain-enhancer of activated B cells (IKB) and nuclear factor kappa B (NF- $\kappa \mathrm{B})$ signaling pathways, and endoplasmic reticulum stress ${ }^{20,32-35}$. Correlation between serum levels of IL-1 $\beta$, IL-6, TNF- $\alpha$, hyaluronan, and lipocalin and disease activity in patients with SLE further highlights the importance of these inflammatory markers in the pathogenesis of $\mathrm{LN}^{17,36-39}$.

The severity of tubulo-interstitial inflammation and injury strongly correlates with poor renal prognosis ${ }^{40}$. We reported that anti-dsDNA antibodies isolated from patients with $\mathrm{LN}$ during nephritic flare can induce secretion of pro-inflammatory mediators such as IL-6, IL-8, TNF- $\alpha$, and MCP-1 through distinct MAPK pathways in cultured PTECs ${ }^{14,39}$ and contribute to the establishment of chemotactic gradients that permit infiltration of immune cells into the tubulo-interstitium. Bi-directional communication occurs between mesangial cells and PTECs, and inflammatory responses occurring in either kidney compartment induced by anti-dsDNA antibodies can provoke a response in the other compartment ${ }^{10}$. Anti-dsDNA antibodies isolated from LN patients in remission can also induce IL-6 secretion in PTECs ${ }^{10}$, a pro-inflammatory cytokine that promotes B-cell differentiation and autoantibody production. Increased IL-6 expression is observed in the kidneys of patients and mice with LN, and infiltrating monocytes/macrophages, mesangial cells, and PTECs are thought to be the predominant source. The findings suggest the possibility of subclinical inflammation, which has important implications on the choice and dose of maintenance immunosuppressive therapy. Current methods for monitoring disease activity do not reliably assess kidney inflammation and fibrosis, and the search for biomarkers which could serve such purposes is ongoing ${ }^{41,42}$.
Of the multitude of pro-inflammatory mediators synthesized by immune and resident renal cells in LN, interferon (IFN) has been implicated in both systemic and end-organ inflammation ${ }^{43}$. Patients with lupus exhibit increased expression of type I IFN response genes $^{43}$. The importance of type I IFN in the development of LN stems from experimental and clinical studies that show reduced autoimmunity in type I IFN receptor-deficient lupus-prone mice ${ }^{44}$, exacerbation of disease following administration of adenovirus encoding IFN- $\alpha$ to lupus-prone mice ${ }^{9,45}$, and the production of lupus-related antibodies in a significant percentage of patients whose hepatitis $\mathrm{C}$ was treated with IFN- $\alpha^{46}$. Whether plasmacytoid dendritic cells are the main source of type I IFN remains controversial. In a murine model of anti-GBM nephritis, resident renal cells rather than infiltrating leukocytes were shown to be the dominant source of type I IFN in the kidney which augmented immune-mediated injury ${ }^{47}$, possibly through TLR-3 activation ${ }^{48}$. Although the investigators did not identify which cells synthesized type I IFN, it is possible that mesangial cells contribute ${ }^{49}$. Regulation of type I IFN in mesangial cells is mediated at least in part by microRNA (miR)-130b, and miR-130b expression is decreased in renal specimens from patients and mice with $\mathrm{LN}^{50}$.

\section{(b) Role of infiltrating cells}

Both innate and adaptive immune systems play critical roles in systemic and intra-renal inflammatory response in LN. Intrarenal deposition of IgG-containing immune complexes alone is insufficient to initiate pathogenesis and must be accompanied by secretion of pro-inflammatory mediators and recruitment of immune cells. Multiple effector mechanisms have been identified in lupus-prone mice and these include but are not limited to Fc receptors (FcRs), type I IFN receptors, IL-6, and MCP- $1^{51-54}$. Engagement of IgG-containing immune complexes with FcRs is a critical step in the development of LN. Although FcRs are present on mesangial cells, FcR activation on circulating hematopoietic cells rather than resident renal cells initiates pathogenesis in lupus-prone mice ${ }^{51}$. Also, the accumulation of apoptotic debris in hematopoietic cells has been reported to promote FcyRImediated PI3K signal transduction and disease development in lupus-prone mice, whereas mice deficient in FcyRI were protected $^{55}$. Monocytes isolated from patients with LN express increased Fc $\gamma \mathrm{RI}$ and exhibit increased MCP-1 secretion and chemotactic potential compared with monocytes from healthy subjects $^{56}$.

Increased serum type I IFN level and induction of IFN-induced gene transcript and protein signature have been observed in peripheral blood mononuclear cells (PBMCs) and renal tissue in patients with $\mathrm{LN}^{43}$. Serum IFN- $\alpha$ in pediatric patients with lupus can induce monocyte maturation into highly active antigenpresenting dendritic cells ${ }^{57}$. These myeloid cells activate naïve $\mathrm{T}$ cells and stimulate B-cell expansion and differentiation through B cell-activating factor (BAFF) and exacerbate autoantibody production and autoimmunity. Exogenous viruses have been suggested as a possible trigger of SLE since double-stranded RNA (dsRNA) viruses can induce IFN- $\alpha$ secretion in dendritic cells, but with the possible exception of Epstein-Barr virus, there are 
limited data to implicate viruses in SLE. Rather, self nucleic acidcontaining immune complexes can activate TLRs, which mediate downstream induction of type I IFN synthesis in PBMCs. Expression of long interspersed nuclear element 1 , a virus-derived nucleic acid present as a transposable element in the human genome, has recently been reported to induce type I IFN in PBMCs and may contribute to the initiation and amplification of $\mathrm{SLE}^{58}$. Oxidative stress, mitochondrial dysfunction, and opsonization of apoptotic cells by complement and IgM have also been implicated in increased type I IFN production and NF- $\kappa \mathrm{B}$ activation in peripheral blood lymphocytes in patients with $\mathrm{SLE}^{59,60}$. Assessment of IFN-inducible gene expression signature rather than IFN secretion may be a more sensitive method to determine IFN activation in patients with lupus and this is due to blocking antibodies that may be present in serum ${ }^{43}$. The roles of IL- 6 and MCP- 1 in the pathogenesis of LN are well established and have been reviewed elsewhere ${ }^{61,62}$.

Chemokine production by infiltrating and resident renal cells mediates the recruitment of monocytes from the circulation and their differentiation into macrophages as they migrate to the site of injury. Macrophages can be divided into two subsets, namely M1 and M2 macrophages ${ }^{63}$. M1 macrophages are classic phagocytic, inflammatory macrophages and are activated in response to IFN- $\gamma$ or TNF- $\alpha$ to secrete large quantities of proinflammatory cytokines that include IL-1, IL-6, IL-12, and IL23. M1 macrophages recruit neutrophils to the site of injury and also induce Th1 and Th17 differentiation ${ }^{64}$. M2 macrophages are activated by IL- 4 and can be subdivided into three groups comprising M2a macrophages that contribute to the reparative process and secretion of anti-inflammatory cytokines, M2b macrophages that are induced by immune complexes or TLR ligation, and M2c macrophages that possess anti-inflammatory and profibrotic properties and play a key role in the elimination of apoptotic cells ${ }^{63,65}$. Owing to their plasticity and presence of pro- or anti-inflammatory cytokine levels within their microenvironment, macrophages can switch from an M1 to an M2 phenotype ${ }^{65}$. Macrophages are key cellular determinants in the pathogenesis of LN and are an important source of key pro-inflammatory cytokines that drive autoimmunity ${ }^{66}$. Their detection in renal biopsies from patients with $\mathrm{LN}$ is associated with crescent formation and poor renal prognosis ${ }^{67,68}$. It has been reported that M1 macrophages were more abundant in class IV LN compared with class II and V LN and were detected predominately in the glomerulus ${ }^{68}$. Macrophages present in tubulo-interstitium belonged to the M2c subgroup, and their number correlated with tubulo-interstitial injury score, anti-dsDNA antibody level, and severity of renal impairment, suggesting a putative role of these cells in tubulo-interstitial injury or fibrosis ${ }^{68}$. The clinical relevance of M2c macrophages is also substantiated by elevated plasma levels of sCD163 (released from M2c macrophages) during active $\mathrm{SLE}^{69}$. Depletion of macrophages using a specific inhibitor to the colony-stimulating factor-1 (CSF-1) receptor in an inducible murine model of LN protected mice from renal inflammation and development of nephritis ${ }^{70}$. Lupus-prone mice deficient in MCP-1 exhibited reduced numbers of interstitial macrophages, decreased proteinuria, and improvement in renal histology ${ }^{54}$. The role of macrophages in experimental models of $\mathrm{LN}$ is dependent on the mouse model used and disease status. In the human setting, CD169+ inflammatory macrophages are present in the glomeruli of patients with $\mathrm{LN}$, but not healthy subjects, and their number correlated with the severity of proteinuria. Glomerular CD169+ macrophages decreased in number after corticosteroid treatment ${ }^{71}$.

B cells are central to LN pathogenesis since they are precursors for autoantibody-producing plasma cells, present antigens to $\mathrm{T}$ cells, and contribute to cytokine secretion. Vimentin expressed by infiltrating inflammatory cells has been reported to serve as an autoantigen that induced in situ B-cell selection during tubulo-interstitial inflammation in $\mathrm{LN}^{72}$. Activated macrophages secrete vimentin in response to pro-inflammatory signaling ${ }^{73}$ and may be a source of vimentin in the tubulo-interstitium. Alternatively, PTECs undergoing epithelial-to-mesenchymal transition (EMT) and apoptosis may also contribute to the vimentin repertoire in the kidney since vimentin is an intermediate filament synthesized by mesenchymal cells and is also expressed on the cell surface of apoptotic cells $\mathrm{s}^{74,75}$. Post-translational modification of vimentin may increase its antigenicity and exacerbate autoimmunity ${ }^{76}$. Elevated anti-vimentin antibody levels are observed in patients with LN, and the level of these antibodies correlated with tubulo-interstitial inflammation ${ }^{72}$. Yet how these autoantibodies contribute to tubulo-interstitial injury remains to be investigated. Anti-vimentin antibodies have also been detected in a proportion of recipients with renal or cardiac allograft, and mycophenolate (MPA) treatment was associated with lower anti-vimentin antibody levels compared with azathioprine in cardiac allograft recipients $^{77,78}$.

\section{Recent knowledge on renal fibrosis in lupus nephritis}

Renal fibrosis is a common feature of chronic inflammatory disorders where wound-healing processes persist and become excessive, with prolonged production of growth factors, fibrogenic cytokines and proteolytic enzymes and their inhibitors, leading to increased synthesis and decreased degradation of the extracellular matrix. Both resident renal cells and immune cells contribute to kidney fibrosis.

\section{(a) Role of resident kidney cells}

Appropriate regulation of inflammation is essential to prevent progressive kidney fibrosis in LN. Fibronectin is the predominant matrix protein present in glomerulosclerotic lesions and is one of the first matrix components to be deposited during tubulointerstitial fibrosis ${ }^{79,80}$. Intra-glomerular fibronectin expression is increased in patients and mice with active $\mathrm{LN}^{15,16}$ and co-localizes 
with IgG deposition, suggesting an association between autoantibody deposition and matrix protein accumulation ${ }^{16}$. We reported that anti-dsDNA antibodies can induce both soluble and fibrillar fibronectin synthesis in mesangial cells and PTECs through increased PKC and MAPK signaling and TGF- $\beta 1$, MCP-1, IL-6, IL-8, and TNF- $\alpha$ secretion ${ }^{14,16}$. Our observation that proinflammatory mediators can also contribute to increased fibrogenesis highlights their multi-faceted functions during pathogenesis. The role of TGF- $\beta 1$ as a key mediator of kidney fibrosis is well established $^{81,82}$, but it is noteworthy that TGF- $\beta 1$ also plays an important role in immune regulation and can suppress B-cell auto-reactivity during the early phase of disease but can exert pro-fibrotic actions when $\mathrm{LN}$ is established ${ }^{81,83}$. Fibrogenic cells are characterized by their ability to synthesize fibrillar collagen. We demonstrated that soluble fibronectin can induce TGF- $\beta 1$ and collagen synthesis in PTECs, thereby amplifying the fibrogenic response of anti-dsDNA antibodies in the tubulo-interstitium ${ }^{14}$. Increased fibronectin has been reported to induce EMT in lung alveolar epithelial cells ${ }^{84}$. It is possible that anti-dsDNA antibody induction of fibronectin induces EMT in PTECs, although further studies are warranted to confirm this. In this regard, we have demonstrated that anti-dsDNA antibodies derived from patients with LN during active disease and remission can induce phenotypic changes in PTECs with the acquisition of an elongated, fibroblastic appearance ${ }^{10}$. Myofibroblasts are the primary source of matrix proteins in renal fibrosis, and these cells may originate from PTECs undergoing EMT, interstitial fibroblasts, or pericytes ${ }^{85,86}$. There is emerging evidence that epigenetics may contribute to the progression of renal fibrosis, and miR-150 has been implicated in tubulo-interstitial fibrosis in patients with $\mathrm{LN}$ through its ability to repress suppressor of cytokine signaling $1^{87}$. In a murine model of chronic kidney disease, reduced fatty acid oxidation in renal tubular epithelial cells appeared to contribute to kidney fibrosis, possibly through mitochondrial dysfunction ${ }^{88}$. The role of fatty acid oxidation in tubular epithelial cells and tubulo-interstitial fibrosis in $\mathrm{LN}$ is not known.

\section{(b) Role of infiltrating cells}

Monocyte-derived macrophages play an important role in tissue fibrosis through direct effects on matrix remodeling or indirectly through the activation of myofibroblasts. Unlike pro-inflammatory M1 macrophages, M2 macrophages exert anti-inflammatory responses and contribute to reparative processes following tissue injury. In immune-mediated injury where the inciting factors persist, M2 macrophages drives fibrogenesis through increased synthesis of growth factors, polyamine and proline ${ }^{89}$ and the generation of a provisional matrix that promotes recruitment and activation of fibroblasts. In animal studies, depletion of macrophages has been shown to reduce the severity of crescentic glomerulonephritis and tubulo-interstitial fibrosis ${ }^{90-92}$. Bone marrow-derived M2 macrophages can undergo myofibroblastic transition and contribute to collagen and $\alpha$-smooth muscle actin expression in areas of kidney fibrosis in patients with IgA nephropathy or rapidly progressive glomerulonephritis ${ }^{93}$. It is possible that M2 macrophages also contribute to kidney fibrosis through a similar mechanism in LN. Although $\alpha$-smooth muscle actin is often associated with myofibroblasts, there is evidence that it is also expressed in the kidney of healthy subjects and neonatal pericytes and thus is not a reliable marker for myofibroblasts ${ }^{94}$. Instead, fibrillar collagen has been suggested to be a more appropriate marker ${ }^{94}$. Of note, renal myofibroblasts lacking $\alpha$-smooth muscle actin expression are associated with increased cell proliferation and collagen production and have been reported to contribute to renal fibrosis ${ }^{95}$.

\section{Current and emerging treatments for lupus nephritis and their effects on inflammatory and fibrotic processes}

Preservation of nephrons is critical in ensuring long-term renal and patient survival ${ }^{1}$. The current standard-of-care induction treatments for severe $\mathrm{LN}$ are corticosteroids combined with either cyclophosphamide (CYC) or $\mathrm{MPA}^{96-99}$. We have reported that MPA can exert a beneficial role on inflammatory and fibrotic processes induced by anti-dsDNA antibodies in human mesangial cells and PTECs and that this role is independent of its immunosuppressive actions ${ }^{14-16,39}$. We have also demonstrated that MPA together with methylprednisolone (MP) was more effective than CYC and MP in preserving renal histology with reduced severity of renal fibrosis in New Zealand black and white first-generation (NZB/W F1) mice, possibly through the ability of MPA to decrease PKC- $\alpha$ activation and TGF- $\beta 1$ expression ${ }^{15}$. Long-term follow-up studies have reported a relatively high incidence of chronic kidney failure in patients with LN previously treated with CYC, especially in subjects with a greater propensity for renal fibrosis, such as African-Americans ${ }^{100-102}$. In a murine model of progressive renal interstitial fibrosis, CYC treatment alone was shown to induce interstitial fibrosis, which was associated with the depletion of macrophages, although the subtype was not determined $^{103}$. Whether exposure to CYC in susceptible individuals tips the balance in favor of fibrosis instead of repair is an intriguing possibility with significant clinical implications. In patients with neoplastic diseases, CYC treatment was associated with urinary bladder inflammation and fibrosis, and the severity of fibrosis was associated with the dose and duration of CYC treatment ${ }^{104}$. It was unclear whether the bladder fibrosis was consequent solely to CYC-induced uroepithelial inflammation or was aggravated by a separate pro-fibrotic effect of CYC. In addition to MMF and CYC, azathioprine and calcineurin inhibitors are used in the treatment of lupus. Whether these pharmacologic agents, in addition to their immunosuppressive actions, can exert a direct effect on kidney inflammation has not been investigated. In contrast, the chronic nephrotoxicity of calcineurin inhibitors has been investigated in organ transplant recipients and is characterized by renal parenchymal fibrosis, vascular hyalinization and prominent induction of TGF- $\beta^{105}$. Angiotensin-converting enzyme (ACE) inhibitors and angiotensin II receptor blockers have been shown to reduce proteinuria and the rate of renal function deterioration in patients with chronic glomerular diseases such as diabetic nephropathy or IgA nephropathy. In patients with quiescent $\mathrm{LN}$ and persistent proteinuria, treatment with ACE inhibitors or angiotensin II receptor blockers resulted in sustained improvements in proteinuria and serum albumin level ${ }^{106}$. Treatment of lupus-prone mice with ACE inhibitors delayed the onset of proteinuria, reduced disease progression and chronic kidney lesions, 
and was associated with decreased intra-glomerular expression of TGF- $\beta 1$ and TGF- $\beta 2$ and splenic production of type 2 cytokines such as IL-4 and IL-10 $0^{107}$. It is conceivable that treatment of lupus patients who have chronic renal damage with blockade of the renin-angiotensin pathway should exert a similar beneficial effect on kidney fibrosis.

Although high-dose corticosteroids remain a cornerstone in the treatment of severe active LN, the use of pulse corticosteroids is highly variable between clinicians ${ }^{96-99}$. Intravenous pulse corticosteroid treatment has been reported to be more effective than oral corticosteroids in suppressing circulating and intrarenal expression of pro-inflammatory cytokines in autoimmune conditions, including $\mathrm{LN}^{108-110}$. Although this should theoretically be accompanied by reduction of renal inflammation, the impact of pulse corticosteroids on renal inflammation and fibrosis remains to be examined.

Biological therapies target key molecules in pathogenic pathways, based on knowledge of the immunopathogenic mechanisms in LN. Biologics tested or being developed in SLE or LN (or both) inhibit B-cell proliferation and activation (for example, anti-BAFF), target B-cell subpopulations (for example, anti$\mathrm{CD} 20$ ), reduce co-stimulatory signal in $\mathrm{T}$ lymphocyte activation (for example, cytotoxic T-lymphocyte associated protein 4 (CTLA4) Ig), or antagonize the effect of key cytokines (for example, IFN- $\alpha)^{111-115}$. Treatment of lupus-prone mice with anti-BAFF or CTLA-4 Ig was shown to ameliorate glomerular inflammation and tubular damage and decrease intra-renal inflammatory cytokine expression $^{116,117}$. Anti-IL-6 monoclonal antibodies were shown to ameliorate nephritis in murine $\mathrm{LN}$ models ${ }^{118,119}$; yet in a controlled trial, the anti-IL-6 antibody sirukumab given for 24 weeks did not reduce proteinuria that persisted despite standard induction immunosuppressive treatment for $\mathrm{LN}$, and the treatment was associated with excessive serious infections ${ }^{120}$. TWEAK (TNFlike weak inducer of apoptosis) is a member of the TNF family of cytokines, and the Fn14 gene codes for the TWEAK receptor. Monocytes, dendritic cells, and natural killer cells are the major sources of TWEAK. Although transient activation of the TWEAK/Fn14 pathway is involved in tissue repair after injury, excessive or persistent activation of the pathway is implicated in autoimmune diseases, including lupus, and activation of the pathway in diseased organs has been reported to drive local inflammation leading to fibrosis ${ }^{121}$. Anti-TWEAK antibody therapy has yielded promising results in animal models of autoimmune diseases $^{122,123}$. A phase II randomized placebo-controlled clinical trial that explored the efficacy, tolerability, and safety of anti-TWEAK antibody as an add-on therapy in patients with class III/IV LN did not demonstrate sufficient efficacy, and the drug development program was terminated (ATLAS study, NCT01499355).

Apart from positive trial outcomes with belimumab and anifrolumab in lupus patients without severe nephritis ${ }^{111,112,124}$, the other clinical trials on biologics to date either failed to achieve the efficacy study endpoints or have been aborted because of perceived unfavorable balance in effect size versus adverse events ${ }^{114,115,125}$. The data nevertheless suggest that a subset of patients could derive clinically observable benefit when these agents were added to conventional immunosuppressive therapies for active $\mathrm{LN}^{113-115}$. Factors contributing to the apparent discrepancy between biological effect and clinical outcomes include efficacy of background therapy, definition of clinical study outcomes ${ }^{126}$, and patient heterogeneity, the last of which was evidenced by the greater impact of rituximab treatment in African-Americans compared with Caucasians ${ }^{114}$. The impact of these agents on renal parenchymal inflammation or fibrosis remains unknown as this is rarely an outcome parameter and the data have not been systematically examined.

\section{Conclusions}

Inflammation and fibrosis are key processes in LN and involve the interplay of immune cells of the innate and adaptive immune system and resident renal cells. The identification of molecules or pathways that contribute to the development of LN has flourished over the past decade and is ever-expanding. Identifying the roles of inflammatory mediators and the molecular mechanism that regulate inflammatory responses is made more challenging by their multi-faceted roles, not only at the onset of pathogenesis but also during the effector phase where they facilitate kidney injury. Defining how these molecules contribute to disease pathogenesis is crucial before more focused therapeutic strategies can be devised. Despite a sound mechanistic rationale and encouraging animal data, the clinical results with biologics have been disappointing to date, yet the failure to demonstrate clinical utility could reflect deficiencies in protocol design rather than a lack of biological effect. There are a number of murine models of LN, and choosing an optimal model is imperative to identify key checkpoints of kidney injury and in the evaluation of potential therapeutic interventions. Table 1 summarizes the phenotypic differences between different murine models of LN. Current therapies primarily target immunological and inflammatory pathways, yet disease mechanisms that lead to myofibroblast conversion and fibrotic processes should not be overlooked. Lastly, given that a multitude of effector mechanisms are activated in patients with LN, biological profiling of patients with a proteomics or genomics approach (or both) may facilitate better selection of treatment regimens.

\section{Abbreviations}

ACE, angiotensin-converting enzyme; BAFF, B cell-activating factor; CTLA-4, cytotoxic T-lymphocyte associated protein 4; CYC, cyclophosphamide; dsDNA, double-stranded DNA; EMT, epithelial-to-mesenchymal transition; FcR, Fc receptor; GBM, glomerular basement membrane; IFN, interferon; Ig, immunoglobulin; IL, interleukin; LN, lupus nephritis; MAPK, mitogenactivated protein kinase; MCP-1, monocyte chemoattractant protein-1; miR, microRNA; MP, methylprednisolone; MPA, 


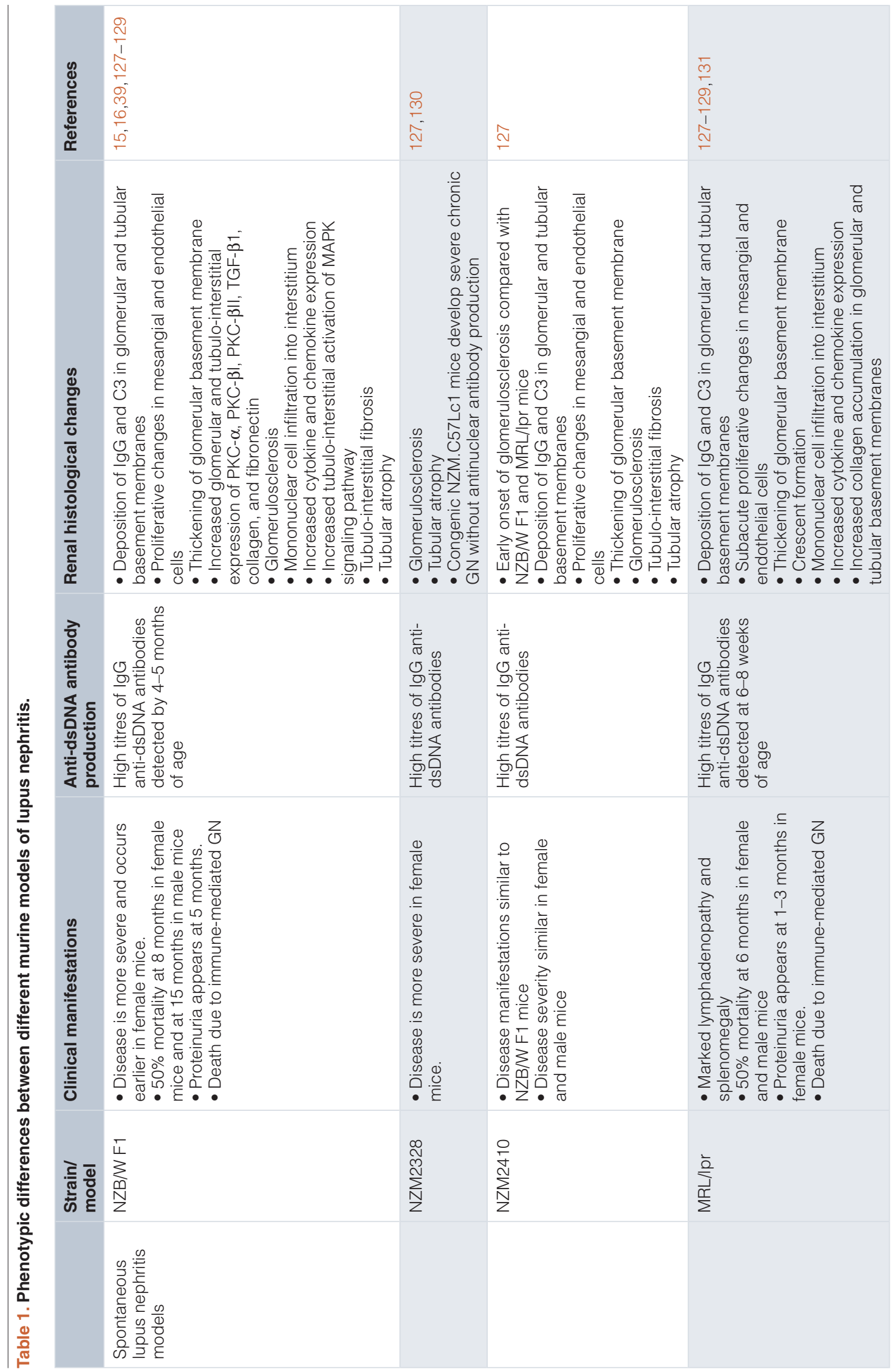

Page 8 of 14 


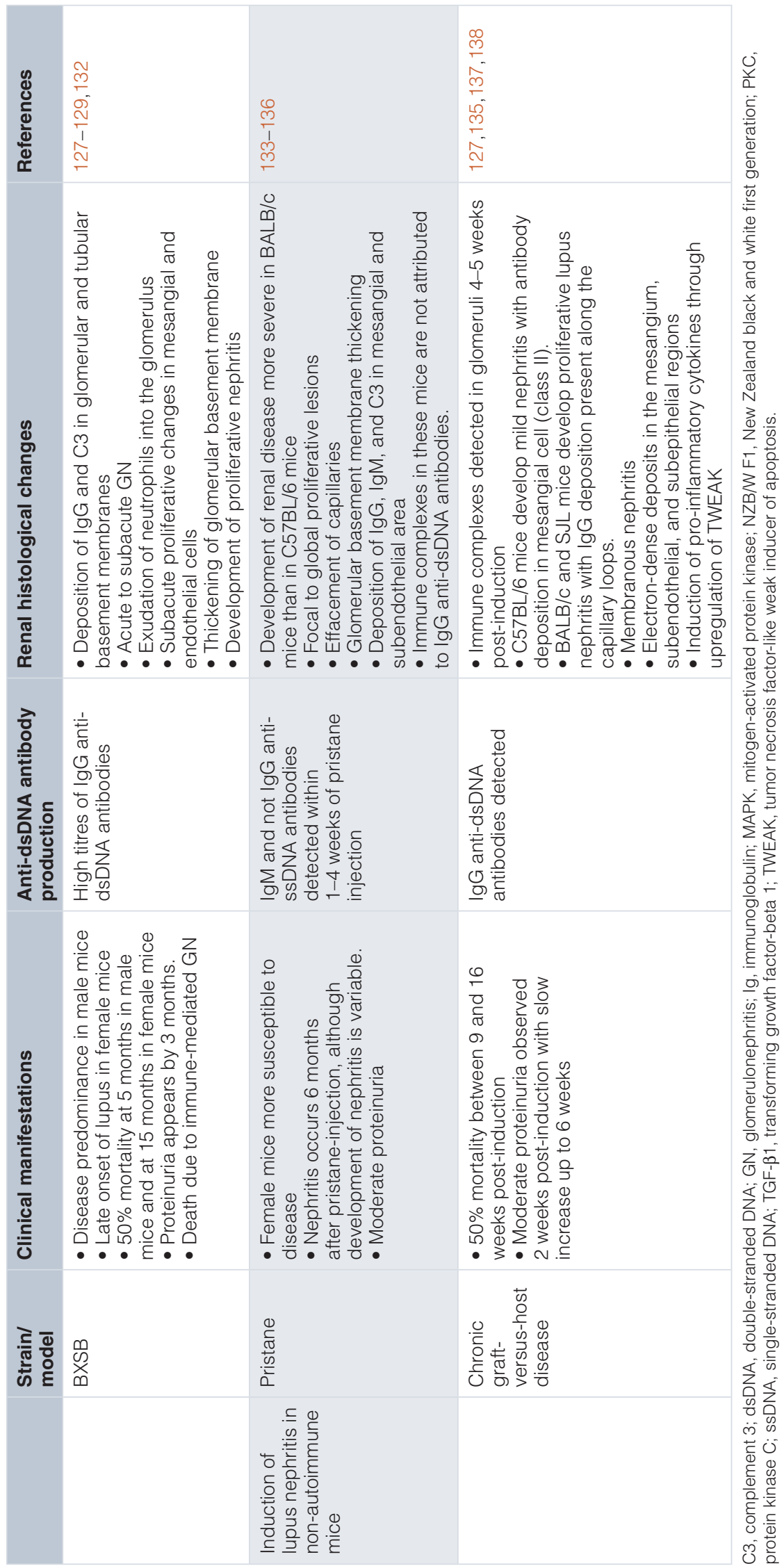


mycophenolate; NF- $\mathrm{B}$, nuclear factor kappa B; PBMC, peripheral blood mononuclear cell; PI3K, phosphoinositide 3-kinase; PKC, protein kinase C; PTEC, proximal tubular epithelial cell; SLE, systemic lupus erythematosus; TGF- $\beta 1$, transforming growth factor-beta 1; TLR, Toll-like receptor; TNF- $\alpha$, tumor necrosis factor-alpha; TWEAK, TNF-like weak inducer of apoptosis.

Competing interests

The authors declare that they have no competing interests.

\section{Grant information}

Studies undertaken by TMC's group [1, 4, 10, 12, 14-17, 22, 31, 39] were funded by the RGC General Research Fund (HKU 7366/04M, 7550/06M, 7604/10M, HKU 7607/12M, 17100914, and 17126814) and UGC Matching Grant Schemes (Phases IV, V, and VI). SY is supported by the Wai Hung Charitable Foundation Limited and the 'Yu Chiu Kwong Professorship in Medicine' Endowment Fund awarded to TMC.

The funders had no role in study design, data collection and analysis, decision to publish, or preparation of the manuscript.
1. Yap DY, Tang CS, Ma MK, et al: Survival analysis and causes of mortality in patients with lupus nephritis. Nephrol Dial Transplant. 2012; 27(8): 3248-54. PubMed Abstract | Publisher Full Text

2. $\quad F$ Bernatsky S, Boivin JF, Joseph L, et al:: Mortality in systemic lupus erythematosus. Arthritis Rheum. 2006; 54(8): 2550-7.

PubMed Abstract | Publisher Full Text | F1000 Recommendation

3. Saxena R, Mahajan T, Mohan C: Lupus nephritis: current update. Arthritis Res Ther. 2011; 13(5): 240.

PubMed Abstract | Publisher Full Text | Free Full Text

4. Chan TM: Treatment of severe lupus nephritis: the new horizon. Nat Rev Nephrol. 2015; 11(1): 46-61.

PubMed Abstract | Publisher Full Text

5. F Tektonidou MG, Dasgupta A, Ward MM: Risk of End-Stage Renal Disease in Patients With Lupus Nephritis, 1971-2015: A Systematic Review and Bayesian Meta-Analysis. Arthritis Rheumatol. 2016; 68(6): 1432-41. PubMed Abstract | Publisher Full Text | Free Full Text | F1000 Recommendation

6. Weening JJ, D'Agati VD, Schwartz MM, et al:: The classification of glomerulonephritis in systemic lupus erythematosus revisited. J Am Soc Nephrol. 2004; 15(2): 241-50.

PubMed Abstract | Publisher Full Text

7. F Dieker J, Tel J, Pieterse E, et al:: Circulating Apoptotic Microparticles in Systemic Lupus Erythematosus Patients Drive the Activation of Dendritic Cell Subsets and Prime Neutrophils for NETosis. Arthritis Rheumatol. 2016; 68(2): $462-72$.

PubMed Abstract | Publisher Full Text | F1000 Recommendation

8. Davidson A, Berthier CC, Kretzler M: Pathogenetic mechanisms in lupus nephritis. In: Wallace DJ, Hahn BH, eds. Dubois' lupus erythematosus and related syndromes. Philadelphia: Elsevier, 2013; 237-55.

Publisher Full Text

9. Triantafyllopoulou A, Franzke CW, Seshan SV, et al.: Proliferative lesions and metalloproteinase activity in murine lupus nephritis mediated by type I interferons and macrophages. Proc Natl Acad Sci U S A. 2010; 107(7): 3012-7. PubMed Abstract | Publisher Full Text | Free Full Text

10. Yung S, Tsang RC, Sun Y, et al.: Effect of human anti-DNA antibodies on proximal renal tubular epithelial cell cytokine expression: implications on tubulointerstitial inflammation in lupus nephritis. J Am Soc Nephrol. 2005; 16(11): 3281-94.

PubMed Abstract | Publisher Full Tex

11. F Chang A, Henderson SG, Brandt D, et al.: In situ B cell-mediated immune responses and tubulointerstitial inflammation in human lupus nephritis. $J$ Immunol. 2011; 186(3): 1849-60.

PubMed Abstract | Publisher Full Text | Free Full Text | F1000 Recommendation

12. Chan TM, Leung JK, Ho SK, et al:: Mesangial cell-binding anti-DNA antibodies in patients with systemic lupus erythematosus. J Am Soc Nephrol. 2002; 13(5): 1219-29.

PubMed Abstract | Publisher Full Text

13. Isenberg DA, Manson JJ, Ehrenstein MR, et al:: Fifty years of anti-ds DNA antibodies: are we approaching journey's end? Rheumatology (Oxford). 2007; 46(7): 1052-6.

PubMed Abstract | Publisher Full Text

14. Yung $\mathrm{S}, \mathrm{Ng} \mathrm{CY}, \mathrm{Ho} \mathrm{SK}$, et al:: Anti-dsDNA antibody induces soluble fibronectin secretion by proximal renal tubular epithelial cells and downstream increase of TGF-ק1 and collagen synthesis. J Autoimmun. 2015; 58: 111-22. PubMed Abstract | Publisher Full Text

15. Yung S, Zhang Q, Chau MK, et al:: Distinct effects of mycophenolate mofetil and cyclophosphamide on renal fibrosis in NZBWF1/J mice. Autoimmunity. 2015; 48(7): 471-87.

PubMed Abstract | Publisher Full Text

16. Yung $S$, Zhang $Q$, Zhang $C Z$, et al:: Anti-DNA antibody induction of protein kinase $C$ phosphorylation and fibronectin synthesis in human and murine lupus and the effect of mycophenolic acid. Arthritis Rheum. 2009; 60(7): 2071-82. PubMed Abstract | Publisher Full Text

17. Yung S, Tsang RC, Leung JK, et al.: Increased mesangial cell hyaluronan expression in lupus nephritis is mediated by anti-DNA antibody-induced IL1beta. Kidney Int. 2006; 69(2): 272-80. PubMed Abstract | Publisher Full Text

18. Chan TM, Yu PM, Tsang KL, et al.: Endothelial cell binding by human polyclonal anti-DNA antibodies: relationship to disease activity and endothelial functional alterations. Clin Exp Immunol. 1995; 100(3): 506-13. PubMed Abstract | Publisher Full Text | Free Full Text

19. Neng Lai K, Leung JC, Bik Lai K, et al:: Anti-DNA autoantibodies stimulate the release of interleukin-1 and interleukin-6 from endothelial cells. J Pathol. 1996; 178(4): 451-7.

PubMed Abstract | Publisher Full Text

20. Zhang $\mathrm{H}$, Zhao $\mathrm{C}$, Wang $\mathrm{S}$, et al:: Anti-dsDNA antibodies induce inflammation via endoplasmic reticulum stress in human mesangial cells. $J$ Transl Med. 2015; 13: 178.

PubMed Abstract | Publisher Full Text | Free Full Text

21. Madaio MP, Hodder S, Schwartz RS, et al.: Responsiveness of autoimmune and normal mice to nucleic acid antigens. J Immunol. 1984; 132(2): 872-6. PubMed Abstract

22. F Yung S, Cheung KF, Zhang Q, et al:: Anti-dsDNA antibodies bind to mesangial annexin II in lupus nephritis. J Am Soc Nephrol. 2010; 21(11) 1912-27.

PubMed Abstract | Publisher Full Text | Free Full Text | F1000 Recommendation

23. Mostoslavsky G, Fischel R, Yachimovich N, et al:: Lupus anti-DNA autoantibodies cross-react with a glomerular structural protein: a case for tissue injury by molecular mimicry. Eur J Immunol. 2001; 31(4): 1221-7. PubMed Abstract | Publisher Full Text

24. Deocharan B, Qing X, Beger E, et al.: Antigenic triggers and molecular targets for anti-double-stranded DNA antibodies. Lupus. 2002; 11(12): 865-71. PubMed Abstract | Publisher Full Text

25. F Olin Al, Mörgelin M, Truedsson L, et al:: Pathogenic mechanisms in lupus nephritis: Nucleosomes bind aberrant laminin $\beta 1$ with high affinity and colocalize in the electron-dense deposits. Arthritis rheumatol. 2014; 66(2): 397-406.

PubMed Abstract | Publisher Full Text | F1000 Recommendation

26. Waters ST, McDuffie M, Bagavant $\mathrm{H}$, et al.: Breaking tolerance to double stranded DNA, nucleosome, and other nuclear antigens is not required for the pathogenesis of lupus glomerulonephritis. J Exp Med. 2004; 199(2): 255-64. PubMed Abstract | Publisher Full Text | Free Full Text

27. Jacob CO, Zang S, Li L, et al.: Pivotal role of Stat4 and Stat6 in the 
pathogenesis of the lupus-like disease in the New Zealand mixed 2328 mice. $J$ Immunol. 2003; 171(3): 1564-71.

PubMed Abstract | Publisher Full Text

28. Alba $\mathrm{P}$, Bento L, Cuadrado MJ, et al.: Anti-dsDNA, anti-Sm antibodies, and the lupus anticoagulant: significant factors associated with lupus nephritis. Ann Rheum Dis. 2003; 62(6): 556-60.

PubMed Abstract | Publisher Full Text | Free Full Text

29. Yung S, Chan TM: Anti-dsDNA antibodies and resident renal cells - Their putative roles in pathogenesis of renal lesions in lupus nephritis. Clin Immunol. 2016; pii: S1521-6616(16)30361-8. PubMed Abstract | Publisher Full Text

30. F Deocharan B, Qing X, Lichauco J, et al.: Alpha-actinin is a cross-reactive renal target for pathogenic anti-DNA antibodies. J Immunol. 2002; 168(6): 3072-8.

PubMed Abstract | Publisher Full Text | F1000 Recommendation

31. Cheung KF, Yung S, Chau MK, et al:: Annexin II-binding immunoglobulins in patients with lupus nephritis and their correlation with disease manifestations. Clin Sci (Lond). 2017; 131(8): 653-71.

PubMed Abstract | Publisher Full Tex

32. Qing X, Zavadil J, Crosby MB, et al.: Nephritogenic anti-DNA antibodies regulate gene expression in MRL/lpr mouse glomerular mesangial cells. Arthritis Rheum. 2006; 54(7): 2198-210.

PubMed Abstract | Publisher Full Text

33. Qing X, Pitashny M, Thomas DB, et al:: Pathogenic anti-DNA antibodie modulate gene expression in mesangial cells: involvement of HMGB1 in antiDNA antibody-induced renal injury. Immunol Lett. 2008; 121(1): 61-73. PubMed Abstract | Publisher Full Text | Free Full Text

34. Im SR, Im SW, Chung HY, et al:: Cell- and nuclear-penetrating anti-dsDNA autoantibodies have multiple arginines in CDR3 of $\mathrm{VH}$ and increase cellular level of pERK and Bcl-2 in mesangial cells. Mol Immunol. 2015; 67(2 Pt B): 377-87.

PubMed Abstract | Publisher Full Text

35. Rovin BH, Tan LC: Role of protein kinase pathways in IL-1-induced chemoattractant expression by human mesangial cells. Kidney Int. 1994; 46(4): 1059-68.

PubMed Abstract | Publisher Full Text

36. McCarthy EM, Smith S, Lee RZ, et al:: The association of cytokines with disease activity and damage scores in systemic lupus erythematosus patients. Rheumatology (Oxford). 2014; 53(9): 1586-94.

PubMed Abstract | Publisher Full Text

37. Hansen C, Otto E, Kuhlemann K, et al:: Glycosaminoglycans in autoimmunity Clin Exp Rheumatol. 1996; 14(Suppl 15): S59-67. PubMed Abstract

38. Pitashny M, Schwartz N, Qing X, et al.: Urinary lipocalin-2 is associated with renal disease activity in human lupus nephritis. Arthritis Rheum. 2007; 56(6): 1894-903

PubMed Abstract | Publisher Full Text

39. Yung $\mathrm{S}, \mathrm{Ng} \mathrm{CY}, \mathrm{Au} \mathrm{KY}$, et al.: Binding of anti-dsDNA antibodies to proximal tubular epithelial cells contributes to renal tubulointerstitial inflammation. Clin Sci (Lond). 2017: 131(1): 49-67.

PubMed Abstract | Publisher Full Tex

40. Nath KA: Tubulointerstitial changes as a major determinant in the progression of renal damage. Am J Kidney Dis. 1992; 20(1): 1-17.

PubMed Abstract | Publisher Full Text

41. F Wolf BJ, Spainhour JC, Arthur JM, et al.: Development of Biomarker Models to Predict Outcomes in Lupus Nephritis. Arthritis Rheumatol. 2016; 68(8): 1955-63.

PubMed Abstract | Publisher Full Text | Free Full Text | F1000 Recommendation

42. F Wu T, Ding H, Han J, et al:: Antibody-Array-Based Proteomic Screening of Serum Markers in Systemic Lupus Erythematosus: A Discovery Study. J Proteome Res. 2016; 15(7): 2102-14.

PubMed Abstract | Publisher Full Text | Free Full Text | F1000 Recommendation

43. F Baechler EC, Batliwalla FM, Karypis G, et al:: Interferon-inducible gene expression signature in peripheral blood cells of patients with severe lupus. Proc Natl Acad Sci U S A. 2003; 100(5): 2610-5.

PubMed Abstract | Publisher Full Text | Free Full Text | F1000 Recommendation

44. Nacionales DC, Kelly-Scumpia KM, Lee PY, et al:: Deficiency of the type I interferon receptor protects mice from experimental lupus. Arthritis Rheum. 2007; 56(11): 3770-83.

PubMed Abstract | Publisher Full Text | Free Full Text

45. Mathian A, Weinberg A, Gallegos M, et al:: IFN-alpha induces early lethal lupus in preautoimmune (New Zealand Black $x$ New Zealand White) $F_{1}$ but not in BALB/c mice. J Immunol. 2005; 174(5): 2499-506.

PubMed Abstract | Publisher Full Text

46. Fukuyama S, Kajiwara E, Suzuki N, et al:: Systemic lupus erythematosus after alpha-interferon therapy for chronic hepatitis $\mathrm{C}$ : a case report and review of the literature. Am J Gastroenterol. 2000; 95(1): 310-2. PubMed Abstract | Publisher Full Text

47. Fairhurst AM, Xie C, Fu Y, et al.: Type I interferons produced by resident renal cells may promote end-organ disease in autoantibody-mediated glomerulonephritis. J Immunol. 2009; 183(10): 6831-8. PubMed Abstract | Publisher Full Text | Free Full Text
48. Anders HJ, Schlöndorff D: Toll-like receptors: emerging concepts in kidney disease. Curr Opin Nephrol Hypertens. 2007; 16(3): 177-83.

PubMed Abstract | Publisher Full Text

49. Zhang $X, \operatorname{Han} X$, Tang $Y$, et al.: miR-744 enhances type I interferon signaling pathway by targeting PTP1B in primary human renal mesangial cells. Sci Rep. 2015; 5: 12987.

PubMed Abstract | Publisher Full Text | Free Full Text

50. $\mathrm{F}$ Han $\mathrm{X}$, Wang $\mathrm{Y}$, Zhang $\mathrm{X}$, et al:: MicroRNA-130b Ameliorates Murine Lupus Nephritis Through Targeting the Type I Interferon Pathway on Renal Mesangia Cells. Arthritis Rheumatol. 2016; 68(9): 2232-43.

PubMed Abstract | Publisher Full Text | F1000 Recommendation

51. Bergtold A, Gavhane A, D'Agati V, et al:: FcR-bearing myeloid cells are responsible for triggering murine lupus nephritis. J Immunol. 2006; 177(10) 7287-95.

PubMed Abstract | Publisher Full Text

52. Crow MK: Advances in understanding the role of type I interferons in systemic lupus erythematosus. Curr Opin Rheumatol. 2014; 26(5): 467-74 PubMed Abstract | Publisher Full Text | Free Full Text

53. Richards $\mathrm{HB}$, Satoh $\mathrm{M}$, Shaw $\mathrm{M}$, et al: Interleukin 6 dependence of anti-DNA antibody production: evidence for two pathways of autoantibody formation in pristane-induced lupus. J Exp Med. 1998; 188(5): 985-90. PubMed Abstract | Free Full Text

54. Tesch GH, Maifert S, Schwarting A, et al:: Monocyte chemoattractant protein 1-dependent leukocytic infiltrates are responsible for autoimmune disease in MRL-Fas ${ }^{\mathrm{Ipr}}$ mice. J Exp Med. 1999; 190(12): 1813-24. PubMed Abstract | Publisher Full Text | Free Full Text

55. F Kang S, Rogers JL, Monteith AJ, et al:: Apoptotic Debris Accumulates on Hematopoietic Cells and Promotes Disease in Murine and Human Systemic Lupus Erythematosus. J Immunol. 2016; 196(10): 4030-9. PubMed Abstract | Publisher Full Text | Free Full Text | F1000 Recommendation

56. Li Y, Lee PY, Sobel ES, et al.: Increased expression of FcgammaRI/CD64 on circulating monocytes parallels ongoing inflammation and nephritis in lupus. Arthritis Res Ther. 2009; 11(1): R6. PubMed Abstract | Publisher Full Text | Free Full Text

57. F Blanco P, Palucka AK, Gill M, et al:: Induction of dendritic cell differentiation by IFN-alpha in systemic lupus erythematosus. Science. 2001; 294(5546): 1540-3. PubMed Abstract | Publisher Full Text | F1000 Recommendation

58. F Mavragani CP, Sagalovskiy I, Guo Q, et al:: Expression of Long Interspersed Nuclear Element 1 Retroelements and Induction of Type I Interferon in Patients With Systemic Autoimmune Disease. Arthritis Rheumatol. 2016; 68(11): 2686-96. PubMed Abstract | Publisher Full Text | Free Full Text | F1000 Recommendation

59. F Buskiewicz IA, Montgomery T, Yasewicz EC, et al.: Reactive oxygen species induce virus-independent MAVS oligomerization in systemic lupus erythematosus. Sci Signal. 2016; 9(456): ra115.

PubMed Abstract | Publisher Full Text | Free Full Text | F1000 Recommendation

60. F Zhuang H, Han S, Li Y, et al:: A Novel Mechanism for Generating the Interferon Signature in Lupus: Opsonization of Dead Cells by Complement and IgM. Arthritis Rheumatol. 2016; 68(12): 2917-28.

PubMed Abstract | Publisher Full Text | Free Full Text | F1000 Recommendation

61. Nishimoto N, Kishimoto T: Interleukin 6: from bench to bedside. Nat Clin Pract Rheumatol. 2006; 2(11): 619-26.

PubMed Abstract | Publisher Full Text

62. Soliman S, Mohan C: Lupus nephritis biomarkers. Clin Immunol. 2016; pii: S1521-6616(16)30257-1.

PubMed Abstract | Publisher Full Text

63. Duffield JS: Macrophages and immunologic inflammation of the kidney. Semin Nephrol. 2010; 30(3): 234-54

PubMed Abstract | Publisher Full Text | Free Full Text

64. Davidson A, Bethunaickan R, Berthier C, et al:: Molecular studies of lupus nephritis kidneys. Immunol Res. 2015; 63(1-3): 187-96.

PubMed Abstract | Publisher Full Text

65. Ricardo SD, van Goor H, Eddy AA: Macrophage diversity in renal injury and repair. J Clin Invest. 2008; 118(11): 3522-30.

PubMed Abstract | Publisher Full Text | Free Full Text

66. F Wynn TA, Chawla A, Pollard JW: Macrophage biology in development, homeostasis and disease. Nature. 2013; 496(7446): 445-55. PubMed Abstract | Publisher Full Text | Free Full Text | F1000 Recommendation

67. Hill GS, Delahousse M, Nochy D, et al:: Predictive power of the second renal biopsy in lupus nephritis: significance of macrophages. Kidney Int. 2001; 59(1): 304-16.

PubMed Abstract | Publisher Full Text

68. F Olmes G, Büttner-Herold M, Ferrazzi F, et al.: CD163+ M2c-like macrophages predominate in renal biopsies from patients with lupus nephritis. Arthritis Res Ther. 2016; 18: 90.

PubMed Abstract | Publisher Full Text | Free Full Text | F1000 Recommendation

69. Zizzo G, Guerrieri J, Dittman LM, et al.: Circulating levels of soluble MER in lupus reflect M2c activation of monocytes/macrophages, autoantibody specificities and disease activity. Arthritis Res Ther. 2013; 15(6): R212. PubMed Abstract | Publisher Full Text | Free Full Text

70. F Chalmers SA, Chitu V, Herlitz LC, et al.: Macrophage depletion ameliorates 
nephritis induced by pathogenic antibodies. J Autoimmun. 2015; 57: 42-52. PubMed Abstract | Publisher Full Text | Free Full Text | F1000 Recommendation

71. Ikezumi Y, Suzuki T, Hayafuji S, et al.: The sialoadhesin (CD169) expressing a macrophage subset in human proliferative glomerulonephritis. Nephrol Dial Transplant. 2005; 20(12): 2704-13.

PubMed Abstract | Publisher Full Text

72. F Kinloch AJ, Chang A, Ko K, et al:: Vimentin is a dominant target of in situ humoral immunity in human lupus tubulointerstitial nephritis. Arthritis Rheumatol. 2014; 66(12): 3359-70.

PubMed Abstract | Publisher Full Text | Free Full Text | F1000 Recommendation

73. F Mor-Vaknin N, Punturieri A, Sitwala K, et al.: Vimentin is secreted by activated macrophages. Nat Cell Biol. 2003; 5(1): 59-63.

PubMed Abstract | Publisher Full Text | F1000 Recommendation

74. Ise H, Goto M, Komura K, et al.: Engulfment and clearance of apoptotic cells based on a GIcNAc-binding lectin-like property of surface vimentin. Glycobiology. 2012; 22(6): 788-805

PubMed Abstract | Publisher Full Text

75. Moisan E, Girard D: Cell surface expression of intermediate filament proteins vimentin and lamin $B_{1}$ in human neutrophil spontaneous apoptosis. $J$ Leukoc Biol. 2006; 79(3): 489-98.

PubMed Abstract | Publisher Full Text

76. Bang $\mathrm{H}$, Egerer $\mathrm{K}$, Gauliard A, et al:: Mutation and citrullination modifies vimentin to a novel autoantigen for rheumatoid arthritis. Arthritis Rheum. 2007, 56(8): 2503-11.

PubMed Abstract | Publisher Full Text

77. Besarani D, Cerundolo L, Smith JD, et al.: Role of anti-vimentin antibodies in renal transplantation. Transplantation. 2014; 98(1): 72-8. PubMed Abstract

78. Rose ML, Smith J, Dureau G, et al:: Mycophenolate mofetil decreases antibody production after cardiac transplantation. J Heart Lung Transplant. 2002; 21(2): 282-5.

PubMed Abstract | Publisher Full Text

79. Eddy AA: Molecular insights into renal interstitial fibrosis. J Am Soc Nephrol. 1996; 7(12): 2495-508.

PubMed Abstract

80. Gharaee-Kermani M, Wiggins R, Wolber F, et al:: Fibronectin is the major fibroblast chemoattractant in rabbit anti-glomerular basement membrane disease. Am J Pathol. 1996; 148(3): 961-7.

PubMed Abstract | Free Full Text

81. Border WA, Noble NA: Transforming growth factor beta in tissue fibrosis. N Engl J Med. 1994; 331(19): 1286-92.

PubMed Abstract | Publisher Full Text

82. Border WA, Noble NA, Yamamoto T, et al:: Natural inhibitor of transforming growth factor-beta protects against scarring in experimental kidney disease. Nature. 1992; 360(6402): 361-4.

PubMed Abstract | Publisher Full Text

83. Liu Y: Renal fibrosis: new insights into the pathogenesis and therapeutics. Kidney Int. 2006; 69(2): 213-7.

PubMed Abstract | Publisher Full Tex

84. F Kim KK, Kugler MC, Wolters PJ, et al.: Alveolar epithelial cell mesenchymal transition develops in vivo during pulmonary fibrosis and is regulated by the extracellular matrix. Proc Natl Acad Sci U S A. 2006; 103(35): 13180-5. PubMed Abstract | Publisher Full Text | Free Full Text | F1000 Recommendation

85. Friedman SL, Sheppard D, Duffield JS, et al:: Therapy for fibrotic diseases: nearing the starting line. Sci Transl Med. 2013; 5(167): 167sr1. PubMed Abstract | Publisher Full Text

86. Nakagawa N, Duffield JS: Myofibroblasts in Fibrotic Kidneys. Curr Pathobiol Rep. 2013; 1(3): 189-198.

PubMed Abstract | Publisher Full Text | Free Full Text

87. F Zhou $\mathrm{H}$, Hasni SA, Perez $\mathrm{P}$, et al:: $\mathbf{m i R}-\mathbf{1 5 0}$ promotes renal fibrosis in lupus nephritis by downregulating Socs1. J Am Soc Nephrol. 2013; 24(7): 1073-87. PubMed Abstract | Publisher Full Text | Free Full Text | F1000 Recommendation

88. $\mathrm{F}$ Kang HM, Ahn SH, Choi $\mathrm{P}$, et al:: Defective fatty acid oxidation in renal tubular epithelial cells has a key role in kidney fibrosis development. Nat Med. 2015; 21(1): 37-46.

PubMed Abstract | Publisher Full Text | Free Full Text | F1000 Recommendation

89. Dzik JM: Evolutionary roots of arginase expression and regulation. Front Immunol. 2014; 5: 544 .

PubMed Abstract | Publisher Full Text | Free Full Text

90. Duffield JS, Tipping PG, Kipari T, et al.: Conditional ablation of macrophages halts progression of crescentic glomerulonephritis. Am J Pathol. 2005; 167(5): 1207-19.

PubMed Abstract | Publisher Full Text | Free Full Text

91. Ko GJ, Boo CS, Jo SK, et al.: Macrophages contribute to the development of renal fibrosis following ischaemia/reperfusion-induced acute kidney injury. Nephrol Dial Transplant. 2008; 23(3): 842-52.

PubMed Abstract | Publisher Full Text

92. Ma FY, Liu J, Kitching AR, et al:: Targeting renal macrophage accumulation via c-fms kinase reduces tubular apoptosis but fails to modify progressive fibrosis in the obstructed rat kidney. Am J Physiol Renal Physiol. 2009; 296(1): F177-85.

PubMed Abstract | Publisher Full Text
93. Meng XM, Wang S, Huang XR, et al.: Inflammatory macrophages can transdifferentiate into myofibroblasts during renal fibrosis. Cell Death Dis. 2016; 7(12): e2495.

PubMed Abstract | Publisher Full Text | Free Full Text

94. Campanholle G, Ligresti G, Gharib SA, et al:: Cellular mechanisms of tissue fibrosis. 3. Novel mechanisms of kidney fibrosis. Am J Physiol Cell Physiol. 2013; 304(7): C591-603.

PubMed Abstract | Publisher Full Text | Free Full Text

95. $\quad$ F Takeji M, Moriyama T, Oseto S, et al:: Smooth muscle alpha-actin deficiency in myofibroblasts leads to enhanced renal tissue fibrosis. J Biol Chem. 2006; 281(52): 40193-200.

PublMed Abstract | Publisher Full Text | F1000 Recommendation

96. Hahn BH, McMahon MA, Wilkinson A, et al:: American College of Rheumatology guidelines for screening, treatment, and management of lupus nephritis. Arthritis Care Res (Hoboken). 2012; 64(6): 797-808. PubMed Abstract | Publisher Full Text | Free Full Text

97. Bertsias GK, Tektonidou M, Amoura Z, et al.: Joint European League Against Rheumatism and European Renal Association-European Dialysis and Transplant Association (EULAR/ERA-EDTA) recommendations for the management of adult and paediatric lupus nephritis. Ann Rheum Dis. 2012; 71(11): 1771-82

PubMed Abstract | Publisher Full Text | Free Full Text

98. Mok CC, Yap DY, Navarra SV, et al.: Overview of lupus nephritis management guidelines and perspective from Asia. Nephrology (Carlton). 2014; 19(1): 11-20. PubMed Abstract | Publisher Full Text

99. KDIGO Clinical Practice Guideline for Glomerulonephritis: Chapter 12: Lupus nephritis. Kidney Int Suppl (2011). 2012; 2(2): 221-32.

PubMed Abstract | Publisher Full Text | Free Full Tex

100. Chan TM, Li FK, Tang CS, et al.: Efficacy of mycophenolate mofetil in patients with diffuse proliferative lupus nephritis. Hong Kong-Guangzhou Nephrology Study Group. N Engl J Med. 2000; 343(16): 1156-62.

PubMed Abstract | Publisher Full Text

101. Illei GG, Austin HA, Crane M, et al:: Combination therapy with pulse cyclophosphamide plus pulse methylprednisolone improves long-term renal outcome without adding toxicity in patients with lupus nephritis. Ann Intern Med. 2001; 135(4): 248-57.

PubMed Abstract | Publisher Full Text

102. Contreras G, Pardo V, Leclercq B, et al:: Sequential therapies for proliferative lupus nephritis. N Engl J Med. 2004; 350(10): 971-80 PubMed Abstract | Publisher Full Text

103. Nishida M, Okumura Y, Fujimoto S, et al.: Adoptive transfer of macrophages ameliorates renal fibrosis in mice. Biochem Biophys Res Commun. 2005; 332(1): $11-6$

PubMed Abstract | Publisher Full Text

104. Johnson WW, Meadows DC: Urinary-bladder fibrosis and telangiectasia associated with long-term cyclophosphamide therapy. N Engl J Med. 1971; 284(6): 290-4

PubMed Abstract | Publisher Full Text

105. Naesens M, Kuypers DR, Sarwal M: Calcineurin inhibitor nephrotoxicity. Clin J Am Soc Nephrol. 2009; 4(2): 481-508. PubMed Abstract | Publisher Full Text

106. Tse KC, Li FK, Tang S, et al.: Angiotensin inhibition or blockade for the treatment of patients with quiescent lupus nephritis and persistent proteinuria. Lupus. 2005; 14(12): 947-52.

PubMed Abstract | Publisher Full Text

107. De Albuquerque DA, Saxena V, Adams DE, et al.: An ACE inhibitor reduces Th2 cytokines and TGF-beta1 and TGF-beta2 isoforms in murine lupus nephritis. Kidney Int. 2004; 65(3): 846-59.

PubMed Abstract | Publisher Full Text | Free Full Text

108. Buttgereit $F$, Wehling M, Burmester GR: A new hypothesis of modular glucocorticoid actions: steroid treatment of rheumatic diseases revisited. Arthritis Rheum. 1998; 41(5): 761-7.

PubMed Abstract | Publisher Full Text

109. Youssef PP, Haynes DR, Triantafillou S, et al:: Effects of pulse methylprednisolone on inflammatory mediators in peripheral blood, synovial fluid, and synovia membrane in rheumatoid arthritis. Arthritis Rheum. 1997; 40(8): 1400-8. PubMed Abstract | Publisher Full Text

110. Yokoyama H, Takabatake T, Takaeda M, et al.: Up-regulated MHC-class II expression and gamma-IFN and soluble IL-2R in lupus nephritis. Kidney Int. 1992; 42(3): 755-63. PubMed Abstract | Publisher Full Tex

111. F Navarra SV, Guzmán RM, Gallacher AE, et al.: Efficacy and safety of belimumab in patients with active systemic lupus erythematosus: a randomised, placebo-controlled, phase 3 trial. Lancet. 2011; 377(9767): 721-31. PubMed Abstract | Publisher Full Text | F1000 Recommendation

112. Furie $\mathrm{R}$, Petri M, Zamani O, et al:: A phase III, randomized, placebo-controlled study of belimumab, a monoclonal antibody that inhibits $B$ lymphocyte stimulator, in patients with systemic lupus erythematosus. Arthritis Rheum 2011; 63(12): 3918-30. PubMed Abstract | Publisher Full Text | Free Full Text

113. Dooley MA, Houssiau F, Aranow C, et al.: Effect of belimumab treatment on rena outcomes: results from the phase 3 belimumab clinical trials in patients with SLE. Lupus. 2013; 22(1): 63-72. PubMed Abstract | Publisher Full Text 
114. F Rovin $\mathrm{BH}$, Furie $\mathrm{R}$, Latinis $\mathrm{K}$, et al:: Efficacy and safety of rituximab in patients with active proliferative lupus nephritis: the Lupus Nephritis Assessment with Rituximab study. Arthritis Rheum. 2012; 64(4): 1215-26. PubMed Abstract | Publisher Full Text | F1000 Recommendation

115. Furie R, Nicholls K, Cheng TT, et al.: Efficacy and safety of abatacept in lupus nephritis: a twelve-month, randomized, double-blind study. Arthritis Rheumatol. 2014; 66(2): 379-89.

PubMed Abstract | Publisher Full Text

116. Ramanujam M, Bethunaickan R, Huang W, et al:: Selective blockade of BAFF for the prevention and treatment of systemic lupus erythematosus nephritis in NZM2410 mice. Arthritis Rheum. 2010; 62(5): 1457-68. PubMed Abstract | Publisher Full Text | Free Full Text

117. Schiffer L, Sinha J, Wang X, et al:: Short term administration of costimulatory blockade and cyclophosphamide induces remission of systemic lupus erythematosus nephritis in NZB/W F, mice by a mechanism downstream of renal immune complex deposition. J Immunol. 2003; 171(1): 489-97. PubMed Abstract | Publisher Full Text

118. Linker-Israeli M, Deans RJ, Wallace DJ, et al: Elevated levels of endogenous IL-6 in systemic lupus erythematosus. A putative role in pathogenesis. $J$ Immunol. 1991; 147(1): 117-23. PubMed Abstract

119. Liang B, Gardner DB, Griswold DE, et al: Anti-interleukin-6 monoclonal antibody inhibits autoimmune responses in a murine model of systemic lupus erythematosus. Immunology. 2006; 119(3): 296-305. PubMed Abstract | Publisher Full Text | Free Full Text

120. F Rovin BH, van Vollenhoven RF, Aranow C, et al:: A Multicenter, Randomized, Double-Blind, Placebo-Controlled Study to Evaluate the Efficacy and Safety of Treatment With Sirukumab (CNTO 136) in Patients With Active Lupus Nephritis. Arthritis Rheumatol. 2016; 68(9): 2174-83.

PubMed Abstract | Publisher Full Text | Free Full Text | F1000 Recommendation

121. Michaelson JS, Wisniacki N, Burkly LC, et al:: Role of TWEAK in lupus nephritis: a bench-to-bedside review. J Autoimmun. 2012; 39(3): 130-42. PubMed Abstract | Publisher Full Text | Free Full Text

122. Zhao Z, Burkly LC, Campbell S, et al:: TWEAK/Fn14 interactions are instrumental in the pathogenesis of nephritis in the chronic graft-versus-host model of systemic lupus erythematosus. J Immunol. 2007; 179(11): 7949-58. PubMed Abstract | Publisher Full Text

123. Molano $A$, Lakhani $P$, Aran A, et al.: TWEAK stimulation of kidney resident cells in the pathogenesis of graft versus host induced lupus nephritis. Immunol Lett. 2009; 125(2): 119-28.

PubMed Abstract | Publisher Full Text

124. F Furie R, Khamashta M, Merrill JT, et al:: Anifrolumab, an Anti-Interferon$\alpha$ Receptor Monoclonal Antibody, in Moderate-to-Severe Systemic Lupus Erythematosus. Arthritis Rheumatol. 2017; 69(2): 376-86. PubMed Abstract | Publisher Full Text | Free Full Text | F1000 Recommendation

125. ACCESS Trial Group: Treatment of lupus nephritis with abatacept: the Abatacept and Cyclophosphamide Combination Efficacy and Safety Study.
Arthritis Rheumatol. 2014; 66(11): 3096-104

PubMed Abstract | Publisher Full Text | Free Full Text

126. F Wofsy D, Hillson JL, Diamond B: Abatacept for lupus nephritis: alternative definitions of complete response support conflicting conclusions. Arthritis Rheum. 2012; 64(11): 3660-5.

PubMed Abstract | Publisher Full Text | F1000 Recommendation

127. Hahn BH, Kono D: Animal models of SLE. In: Wallace DJ, Hahn BH, eds. Dubois Lupus Erythematosus and Related Syndromes. 8th ed. Philadelphia: Elsevier Saunders; 2013; 190-236. Publisher Full Text

128. Blatt NB, Glick GD: Anti-DNA autoantibodies and systemic lupus erythematosus. Pharmacol Ther. 1999; 83(2): 125-39. PubMed Abstract | Publisher Full Tex

129. Grande JP: Experimental models of lupus nephritis. Contrib Nephrol. 2011; 169 $183-97$.

PubMed Abstract | Publisher Full Tex

130. Ge Y, Jiang C, Sung SJ, et al:: Cgnz1 allele confers kidney resistance to damage preventing progression of immune complex-mediated acute lupus glomerulonephritis. J Exp Med. 2013; 210(11): 2387-401. PubMed Abstract | Publisher Full Text | Free Full Text

131. Li L, Nukala S, Du Y, et al.: Murine lupus strains differentially model unique facets of human lupus serology. Clin Exp Immunol. 2012; 168(2): 178-85. PubMed Abstract | Publisher Full Text | Free Full Text

132. Murphy ED, Roths JB: A Y chromosome associated factor in strain BXSB producing accelerated autoimmunity and lymphoproliferation. Arthritis Rheum. 1979; 22(11): 1188-94. PubMed Abstract | Publisher Full Text

133. Reeves WH, Lee PY, Weinstein JS, et al.: Induction of autoimmunity by pristane and other naturally occurring hydrocarbons. Trends Immunol. 2009; 30(9): 455-64. PubMed Abstract | Publisher Full Text | Free Full Text

134. Satoh M, Kumar A, Kanwar YS, et al:: Anti-nuclear antibody production and immune-complex glomerulonephritis in BALB/c mice treated with pristane. Proc Natl Acad Sci U S A. 1995; 92(24): 10934-8. PubMed Abstract | Publisher Full Text | Free Full Text

135. Xu Y, Zeumer L, Reeves WH, et al.: Induced murine models of systemic lupus erythematosus. Methods Mol Biol. 2014; 1134: 103-30. PubMed Abstract | Publisher Full Text

136. McGaha TL, Madaio MP: Lupus Nephritis: Animal Modeling of a Complex Disease Syndrome Pathology. Drug Discov Today Dis Models. 2014; 11: 13-8. PubMed Abstract | Publisher Full Text | Free Full Text

137. Bergijk EC, Munaut C, Baelde JJ, et al:: A histologic study of the extracellular matrix during the development of glomerulosclerosis in murine chronic graft-versus-hos disease. Am J Pathol. 1992; 140(5): 1147-56. PubMed Abstract | Free Full Text

138. Bruijn JA, van Elven EH, Hogendoorn PC, et al:: Murine chronic graft-versus-host disease as a model for lupus nephritis. Am J Pathol. 1988; 130(3): 639-41. PubMed Abstract | Free Full Text 


\section{Open Peer Review}

\section{Current Peer Review Status:}

\section{Editorial Note on the Review Process}

Faculty Reviews are review articles written by the prestigious Members of Faculty Opinions. The articles are commissioned and peer reviewed before publication to ensure that the final, published version is comprehensive and accessible. The reviewers who approved the final version are listed with their names and affiliations.

\section{The reviewers who approved this article are:}

\section{Version 1}

\section{Chaim Putterman}

Department of Medicine, Albert Einstein College of Medicine, Bronx, NY, USA

Competing Interests: No competing interests were disclosed.

\section{Anne Davidson}

Feinstein Institute, Center for Autoimmunity and Musculoskeletal Diseases, Manhasset, NY, USA

Competing Interests: No competing interests were disclosed.

The benefits of publishing with F1000Research:

- Your article is published within days, with no editorial bias

- You can publish traditional articles, null/negative results, case reports, data notes and more

- The peer review process is transparent and collaborative

- Your article is indexed in PubMed after passing peer review

- Dedicated customer support at every stage

For pre-submission enquiries, contact research@f1000.com 